\title{
Urban Environmental Management in Latin America, 1970-2017
}

\author{
David J. Edelman', Micaela Schuster², Janett Said1 \\ ${ }^{1}$ School of Planning College of Design, Architecture, Art and Planning, University of Cincinnati, Cincinnati, USA \\ ${ }^{2}$ Institute for Housing and Urban Development Studies, Erasmus University, Rotterdam, The Netherlands \\ Email: edelmadj@ucmail.uc.edu
}

How to cite this paper: Edelman, D. J., Schuster, M., \& Said, J. (2017). Urban Environmental Management in Latin America, 1970-2017. Current Urban Studies, 5, 305331. https://doi.org/10.4236/cus.2017.53017

Received: July 26, 2017

Accepted: August 19, 2017

Published: August 22, 2017

Copyright (c) 2017 by authors and Scientific Research Publishing Inc. This work is licensed under the Creative Commons Attribution International License (CC BY 4.0).

http://creativecommons.org/licenses/by/4.0/

\begin{abstract}
While Urban Environmental Management has received increasing worldwide attention in the last 50 years, much of the international attention to this growing field has focused, as is the case with most scientific fields, on the English language literature. Nevertheless, much professional work of interest has been taking place in Latin America, where the problems of the urban environment have been identified early and considered major difficulties in the development of this heavily urbanised region. Consequently, the purpose of the research that this article summarises is to address the Spanish and Portuguese language literature written in Latin America on Latin America itself to identify the trends in the field that have emerged, and are continuing to emerge, there and, eventually, to determine what lessons they offer to other regions.
\end{abstract}

\section{Keywords}

Urban Environmental Management, Latin America, Cities, Urban Planning, Sustainability, Spanish, Portuguese

\section{Introduction}

Urban Environmental Management has been receiving increasing attention since 1970 in both developed countries, where it has emerged as a subject of academic research and professional interest, and in developing countries, where it has become increasingly an area of donor concern as well. As a field, it is more like planning or engineering rather than geography, economics or sociology; and it represents an integrated view of environmental problems at city, and increasingly, regional level. Such problems are multi-sectoral (e.g., manufacturing, services, household, etc.), multi-system (e.g., water supply, sanitation, transport, 
etc.), multi-level (central, regional, local and community) and multi-actor (e.g., government, NGO, $\mathrm{CBO}$ and private). They require solutions of enormous complexity, and those professionals who coordinate the planning, implementation and management of the process must be able to communicate with specialists from many disciplines and professions (e.g., biology, chemistry, engineering, city planning, public administration, social sciences and law

Theoretical and conceptual work in the field, however, has been thin and sporadic to date. This, of course, does not mean that there has been no theoretical or conceptual work done with relevance to the field. The term, Urban Environmental Management was first mentioned by Brian J.L. Berry and Frank E. Horton as the title of their 1974 book on planning for pollution control. Others who have contributed to the field include Carl R. Bartone (1989) and Josef Leitmann (1994) of the World Bank, the Canadian geographers William Rees (1996), Richard Stren (1992), Rodney White and Joe Whitney (1992), Kenneth J. Button and David W. Pearce (1989), the planner Richard Meier and his associates at Berkeley (1981), Jorge E. Hardoy and David Satterthwaite of IIED in the UK (1989), the English writer and filmmaker Herbert Giradet (1992), S. Galilea (1994), E. Ocon (1994), E. Leff, (1998), R.G.J. Boon et al. (2001), Miriam Alfie Cohen (2007), L.M. Santana Rodríguez et al. (2010), M.C. Sánchez et al. (2010), and P. Avila Garcia (2012), among others.

However, there is as yet little or no work that has been done on developing a comprehensive theory of the entire process of urban environmental interactions. Perhaps even more striking is the fact that there is only one university text on the subject (Leitmann, 1999), and it is out of print. So it seems that there are good grounds for some interesting research that has yet to be attempted by the academic community. The most important need stressed in the literature for the last fifty years has been to develop a new framework for policy; that is, to create the possibility for change. This is why the development of a comprehensive theory is significant.

In the absence of such a theory, however, one could first consider the problems such a theory would help to explain and provide the policy framework for it. In Latin America, by the 1990's, the most important of these urban environmental problems were grouped by three different themes, i.e., 1) the problems comprising the brown agenda, 2) those, of the grey agenda and 3) the difficulties involved in managing both. These are considered to be quite separate from those environmental issues facing the entire plant and animal world, including humans (the green agenda), which include issues such as the preservation of species, global warming, rain forest preservation, etc. In Latin America, such green agenda topics provided the initial theme from which sustainability was introduced, and an approach, however inadequate, to guide more complex issues such as those within the brown and grey agendas (Vásconez, 2000).

The brown agenda is focused exclusively on mankind and the effects of the systems humans have created primarily, but not exclusively, on themselves. The 
issues of concern here include water supply; sanitation and drainage; solid waste; emissions from cars, trucks, buses and low-grade domestic fuels; congestion and crowding; noise, and the human occupation of lands with a sensitive green environment. These are problems common to all cities, although particular problems dominate in particular cities. Thus, Mexico City and Santiago are plagued by motor vehicle generated air pollution, while Lima has extreme difficulty in providing clean water to the stream of rural-urban immigrants. A further distinction is also made between these problems and those of the grey agenda, which are concerned with industrial pollution of the air, soil and water, including that of hazardous waste, as well as factory and fossil-fueled power plant emissions.

For many years, the important issue for discussion in the context of Urban Environmental Management in Latin America has been whether to deal separately with the problems of the brown agenda, most of which are poverty induced, and the problems of the grey agenda, which are directly related to production. The two sets of problems need to be confronted in different ways. Some cities have only one or the other set of problems, while some have both (Edelman, 1998).

A third set of critical problems concerns management. As Mitlin and Satterthwaite have pointed out (1996), the urban environment cannot be managed strictly within the confines of a city's political boundaries. Instead, local, regional and national frameworks for management are necessary. In the Latin American context, local refers not to municipalities, but rather to the urban agglomerations composed of numerous municipalities. For example, Metropolitan Lima is divided into over 40 municipalities, each responsible for garbage collection. In rich areas, this goes well; in poor areas not so well. In Bolivia, under its system of devolution of administrative responsibility, each of the country's 311 municipios includes an entire municipality plus its hinterland, but many do not have functioning institutions to manage the array of environmental problems they face, but in many other countries, environmental management remains highly centralised, and insufficient attention is paid to the different institutions involved in the management process, each with its own mandate and area of geographic responsibility.

The more recent literature of Urban Environmental Management suggests a shift from the initial compartmentalized and thematic discussion about challenges for cities, such as the difficulties of dealing with these issues separately. At present, more work acknowledges the complexity and interconnectedness of these issues, and consequently, the discussion focuses on the need for public sector led systematic change to address these pressing urban issues in a preventive rather than a reactive manner.

The important issue for discussion here, then, is what sort of flexible and pragmatic institutional structure is appropriate for managing the environmental problems of urban areas in Latin America. It is appropriate to explore the 
framework levels of Mitlin and Satterthwaite in this regard, as well as different organisational models at each of the levels. What works in one country may not be successful in another. However, the approach to developing frameworks would be the same in all cases.

Beyond these three initial sets of problems, which are technical and managerial, a fourth set of critical problems relates to a lack of knowledge and awareness of, and/or concern with, urban environmental problems by both the general public and policy makers in general. While much of the general public might be affected by the ignorance of poverty, public officials are not. For them, the reality of their political circumstances simply puts higher priority on other, generally economic, concerns. In this context, the important issue for discussion is how to raise the level of attention given to the urban environment by both the public and its representatives.

Of interest here, however, is the fact that much of the international attention to this new and growing field has focused, as is the case with most scientific fields, on the English language literature. That is, most of the knowledge on emerging environmental issues occurs in centers of research and technological development of the "North," pointing to a lack of capacity in scientific and technological self-determination to feed sustainable policy development in Latin American countries (Fernández, 2000). Nevertheless, much professional work of interest has been taking place in Latin America, where the problems of the urban environment have been identified early and considered major difficulties in the development of this heavily urbanised region. The former President of the Interamerican Development Bank (IADB), Enrique Iglesias, has stressed the importance of cities, democratisation, decentralisation and infrastructure, among other themes important in the urban sector of Latin America. These points converge in the urban environment.

Consequently, the purpose of the research that this article summarises is to address the Spanish and Portuguese language literature written in Latin America on Latin America itself to identify the trends in the field that are emerging there and, eventually, to determine what lessons they offer to other regions.

\section{Structure of the Paper and Research Methodology}

The work described here has been a desk study based on Internet research, and it is divided into two phases. Phase I covers the period from 1970, just prior to Habitat I in Vancouver (1976), to 1998, two years after Habitat II in Istanbul (1996). This work has been published in Spanish (Schuster and Edelman, 2002) and English (Schuster and Edelman, 2003). Phase II builds on, modifies and expands the previous work to cover the period from 1998 until 2017. Habitat III in Quito (2016) brought the global discussion of urbanization and Urban Environmental Management to the heart of Latin America. As most who have tried to do so know, navigating through the Internet and struggling to identify and obtain as much information as possible in countries where this type of data 
access is not always available is not always easy, but in the end, it proved a fruitful effort. The first step in the initial study (Phase I) was to identify as many books on the topic as possible and find summaries or annotations of them. From all the information received, it became quite clear early on that the trends for Latin America could be divided into four historical periods. i.e.:

a) $1970 / 1979$

b) $1980 / 1989$

c) $1990 / 1992$

d) $1993 / 1998$

However, the Phase II analysis identified one further historical period with its own unique characteristics; i.e.:

e) $1999 / 2017$

To confirm the conclusions drawn from an analysis of the books found through the Internet, a second stage of the research was undertaken in both phases to search the Internet once again, this time for journals and magazines specialised in environment related matters. The same time periods were utilised to see if the trends identified in the books were paralleled by those in the periodic literature. The research approach was somewhat different, however. During the research, it became clear that most books of interest are found at the Internet sites of national libraries, which give access to other countries as well. Thus, sometimes only one Internet site would provide a sufficient range of information of a certain type so that it would not be necessary to search out another site. The United States Library of Congress holdings, for example, are very extensive. Journals or magazines, on the other hand, are of many types, national, regional and international, ranging from commercial promotional publications for industries, to publication arms of specialised organisations, to the magazines of professional societies to university faculty or institute publications to heavily refereed journals of international academic stature. Moreover, the periodic literature changes over time with new journals and magazines emerging and older ones disappearing. This is especially true of digital, Internet-based publications. Thus, a number of the Internet sites consulted in Phase I no longer existed by Phase II, but they were, nevertheless, replaced by similar sites. Many changes have taken place with the Internet in the forty-seven year span of this study.

Clearly, then, in order to keep up with the developments in any field from such a wide array of materials, country-by-country research was and remains essential. However, the Latin American region is very large, and not all countries are places of active research or professional practice in Urban Environmental Management. Consequently, a selection of seven countries representative of the Spanish and Portuguese language countries of the Western Hemisphere was made. They vary in size, location and level of development, but include most of the region's urban (and overall) population; and all have recognised the severity of the problems of the urban environment and have active professional and academic institutions attempting to deal with them. These countries are Argentina, 
Brazil, Chile, Colombia, Cuba, Mexico and Peru. Some additional literature peripherally addresses El Salvador, Ecuador, Venezuela and Latin America as a region.

\section{The Latin American Context}

Trends in the literature of Urban Environmental Management cannot be analysed without understanding the overall historical context of the region. This is the case, at least in Latin America, for which the evolution of the literature of interest to this research is a clear reflection of regional history. As David Goodman and Michael Redclift (1991) have stated:

Latin \& Central America, even before its official discovery, was looked upon by Europeans as the gateway to the Indies; it came to represent an apparently inexhaustible supply of everything that Europeans needed. Locked up within its vast jungles and tractless mountain ranges was a store of natural resources that could be translated into wealth. It required ingenuity, and the hard labour of (largely) unwilling hands, to convert these treasures into tangible material benefits. The image of Latin America in European art, as Baddeley and Fraser (1989) demonstrate, is bound up with the otherness of the continent. This distance, usually portrayed as the distance between primitive and civilised values, justified the Spaniards and the Portuguese in their conquest of the Americas, and enabled them to put a seal on their conquest by destroying those whose lives were lived closest to nature, the indigenous population of the continent.

The vestiges of the historical images conjured up by this paragraph provide a context that even in the present day help shape a wide range of development issues, including those of the environment in general and the urban environment in particular. Social, political, cultural and environmental issues have been strongly delineated by the internal and external economic processes that have taken place in Latin America, and it is the latter that has contributed to the largest extent to the development of this region.

Unlike in France, there is no clearly identifiable point in time (late 1960s) at which an organised ecological movement was founded in Latin America, although the UN Conference on the Environment held in Rio in 1992 had a substantial impact on the sustainability discourse of Urban Environmental Management in the region. Instead, environmental themes appeared gradually due to external pressures as a consequence of the economic dependency of the region on Europe, and even more so, on North America. Even though some early literature on environmental matters can be found, the focus is on the technological aspects rather than on the sustainability of any technology-a trend that has recently been changing (i.e., in the 1990's). An example is the case of agriculture. Any serious study of Latin America's history since 1492 must recognise the importance of land use for plantation agriculture and rent (in the form of the labor of the indigenous population). This unsustainable and extractive form of industrial farming replaced the indigenous population's cultivation of native varieties 
of plants, such as tobacco, manioc, maize and potato, and their carefully balance-ed and sustainable system of resource use for production.

History shows that later a similar evolution occurred during the period of industrialisation. During the early decades of this century, several Latin American countries made important strides in their industrialisation, a process which was well advanced in countries such as Argentina, Brazil, Chile and Mexico by the 1940s. The industrial development of the larger Latin American economies was based on import substitution, and the model for development was that provided by Western Europe and the United States. Governments in Latin America assumed that pursuing industrial growth would enable the region to reduce its external dependency and, eventually, to develop a large internal market for the products of its own industries (Redclift and Goodman, op. cit.). This model, as is well known, has failed. Moreover, it created patterns of high consumption, and raised consumer expectations. Development continued, of course, but within a model of dependency that continues, along with the more recent globalisation of the world economy.

This globalisation means that Latin America's participation in the world economy and its international markets is dependent upon, among other requirements, compliance with rising international environmental standards. In the struggle for international market share, countries in the region have started to develop an environmental policy profile, so as not to be discriminated against by the rest of the world. It has become a major task for governments to confront their legal and institutional limitations and management needs, as well as to recognise their natural resource potential. This implies giving higher priority to the environmental management of natural resources; defining more clearly institutional responsibilities and ensuring that more interests are represented; participating in the definition of international environmental management standards (e.g., ISO 14000), and exploring further the use of economic instruments for tackling environmental problems. None of this is, of course, urban, and the urban trends will be discussed in more detail later in this paper. The essential point to make here, however, is that this search for an overall environmental policy and strategy is necessary in each country. Of course, each country has its own history, social fabric and institutions, so the model adopted will vary; and some countries will achieve more than others in this regard. Nevertheless, the trend region-wide towards better environmental stewardship is apparent, and this is clear from the research of the literature on Urban Environmental Management that has been conducted for this article.

\section{Trends in the Literature}

The trends uncovered in literature on Urban Environmental Management reflect the evolution of history and overall environmental sensitivity explained in the previous section. To enable the reader to visualise the trends, Figure 1 has been developed. 


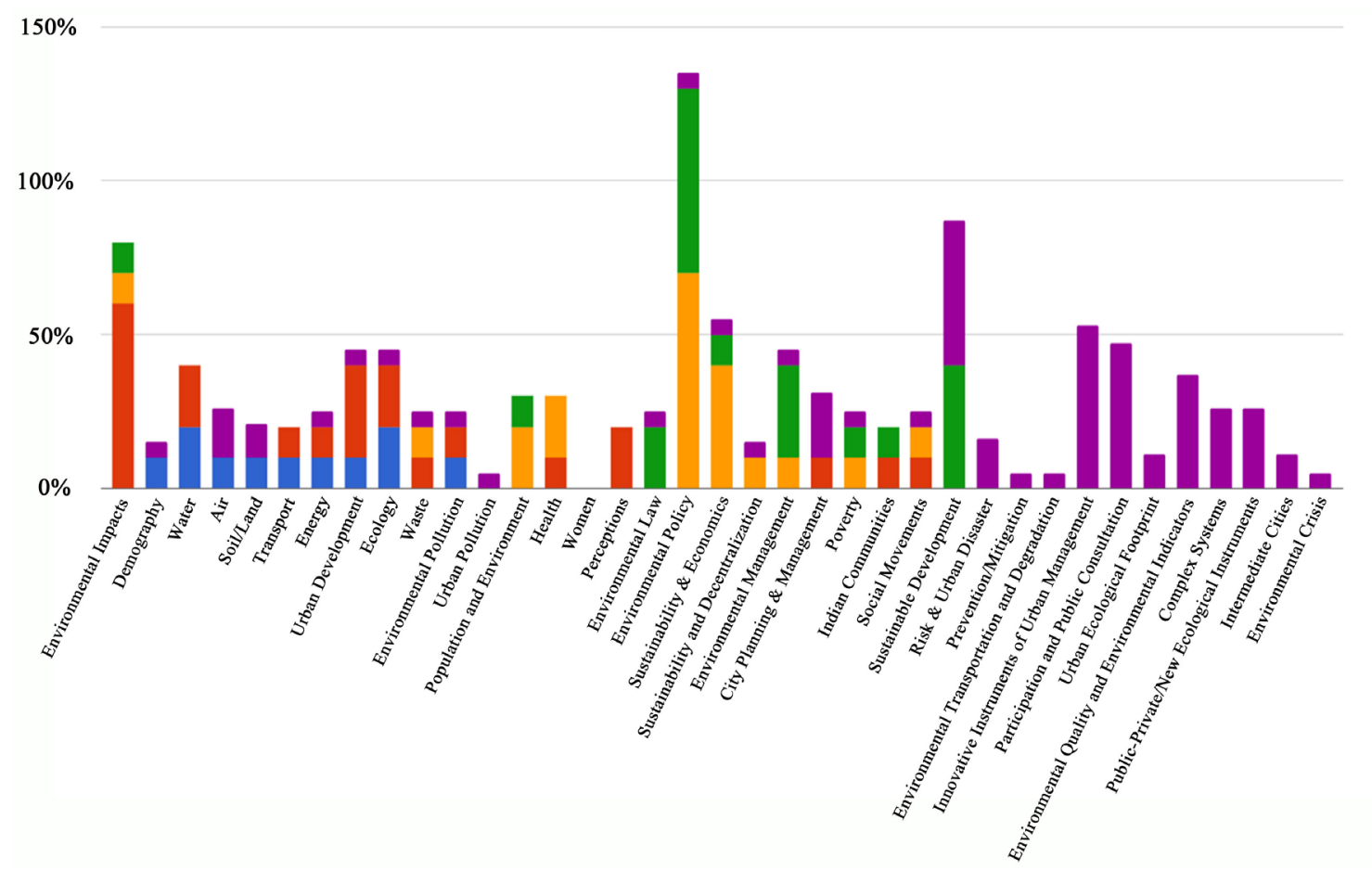

Figure 1. Trends in the Latin American literature on urban environmental management.

Each of the time periods mentioned in Section 2 and the corresponding urban environmental themes characterising the literature of the period, both of which can be seen in the figure, are discussed below. In order to clarify the significance of the themes at a given point in time, the words appearing on the bottom axis of the figure represent a short Key Word List of important themes, which emerged from the Internet research. Each key word, which occurred in the Latin American literature during each period, was counted, and the books for which they were cited accessed. These were then reviewed and the relevant books selected as occurrences of the key words. This point requires a bit of further explanation.

Utilising the search engine provided by the Internet sites, a long list of key words was first input to identify the body of bibliographic literature found in books. However, as is common with this type of search, many secondary sources that do not necessarily relate very closely to the key words that have been entered are identified. Thus, it was then necessary to look at the content of each reference and analyse its correlation with each key word. Those key words that were found to shed no light on trends in the field were then dropped. That is, words that produced few or no useful references were eliminated. In this way, the Key Word List in Figure 1 was developed. Once the books were reviewed, the same procedure was applied to the periodic literature. All the references that have emerged in this study are, therefore, the result of this procedure; and, together, they form a picture of the most important issues per period, as well as the developing trends for the region over time. This Key Word List is repeated in the Section 11 Annex at the end of this paper, along with the percentage of occur- 
rence per period for each word in all five periods, which is displayed in Figure 2 in the Annex.

\section{- The 1970 to 1979 Period: Environmental Compartmentalisation}

Demography, water, air, soil and land, transport, energy, ecology, waste, urban development and environmental pollution are the most salient environmental themes appearing in the Urban Environmental Management literature of this period. Since each of these themes was treated as a matter for separate study, and no interrelationships appear among them in the literature, this period has been identified in the research as the period of Environmental Compartmentalisation. Historically, this was a period of rapid population growth, and genuine development in the region. Living standards rose significantly. The conservation of the Amazon forests emerged as the first great green environmental issue. With regard to the urban environment, it is the period in which studies of water systems; the effects of energy production and use in cities; the meteorological aspects of air contamination, etc. try to describe the effects of the rapid growth and development phase of this period of urban based import-substitution driven industrialisation.

\section{- The 1980 to 1989 Period: Environmental Implications of Development}

The environmental impacts of agricultural systems, human ecology, energy and ecology, urban transportation and its pollution, community development, as well as Indian communities and the environment are the key issues of this period. Migration to metropolitan cities and the growing population, both consequences of the previous period, along with the effects of the two oil crises of the 70 s and the disastrous debt situation that affected development throughout Latin America, were factors that undermined the general economic improvement characterising the region in the 70s. Thus, the 1980s was a period of severe economic recession. Available jobs for poor urban immigrants vanished, and living standards fell abruptly. Social conditions, such as race, language, income and gender became crucial determinants of social position.

The important point here regarding this economic crisis is that it became a leading factor in fostering the period's new perception of the environment. At this time, Latin American countries were confronted by a mix of factors that reflected the past, while they first began to exhibit signs of future urban environmental trends. That is, past development policies began to have negative consequences and implications for the environment during this period. The growing literature on the implications of, for example, the technological model of agriculture pursued in much of the region; solid waste generation, collection and disposal for the inhabitants of cities; the quality of water supply networks for this increasing urban population; the consequences of resource exploitation in underdeveloped areas; the quality of urban life in the region; the impacts of human activities on nature, etc. portrayed the consequences of past development policies on the economic crisis, which touched every aspect of urban life, including the environment. 
At the same time, a new trend in the literature describes the consequences of the crisis for Latin America's social movements. Indigenous communities made themselves heard after decades of being discriminated against in silence, and they began to claim the right of ownership of much of the natural heritage in a number of countries to halt its exploitation by civilisation. While this has little to do with the urban environment, the strengthening of social movements around environmental issues has developed into an important force in the 1990s. This has primarily taken shape at the community level in the poor areas of the region's megacities, with Lima (Miranda et al., 1996) and Rio de Janeiro (Edelman et al., 1997) providing notable examples.

Finally, the economic crisis of Latin America in the 1980s has become a persistent reminder of a history of poor development planning by lingering in many countries as a debt crisis even after an economic turnaround has taken place. This economic growth, which has put so much pressure on the urban environment, has also made clear the importance of preserving natural resources. Pressured by developed countries, some governments decided to accept the Green Solution to their debt problem through so-called Debt-for-Nature Swaps. These exchanges both reduce the national debt and save the environment. Typically, international environmental groups would buy a country's discounted debt on the financial markets and turn this over to the debtor government, which would then commit local currency to create a national park, for example, which would still be owned by the government and hence generate revenue for it.

Unfortunately, none of the options to reduce the debt during the 80 s, including the debt swap concept, was really effective. While this issue had little to do with the urban environment per se during that period, it nevertheless brought to the consciousness of the urban population the fact that the environment had value. Moreover, by the end of the decade there was a growing international awareness of the inter-relationships between the plight of the poor and environmental degradation, and the need to pursue a pattern of development, which at least had some chance of being sustainable (O'Brien, 1991).

Perhaps the most significant development in the literature of this period for the development of the field of Urban Environmental Management, however, is the appearance of urban literature on development. While in this period, all literature in some way related to the environment continued to focus solely on ecological aspects, such as water pollution, water quality, air pollution, soil contamination, and most literature related to development concerned regions or countries, the Latin American development literature began to take on an urban focus. In terms of economic and technological growth, population growth, and the social consequences of both, job creation reflecting these developments was increasingly an urban phenomenon, which accelerated urban migration. Urban literature of the time was hence concerned with the growth and development of the cities in the region, without relating this historic and social transformation to that literature focused on the environmental implications of human activities. 
The two bodies of literature remained separate.

- The 1990 to 1992 Period: Economic Development and Sustainability

With the recognition of the interrelationships between the Latin American economic crisis of the 1980s and environmental conditions, a turning point was reached in the environmental literature of the region. The early 90 s was a period when the literature became far more explicit in recognising the relationships between economic development and environmental consequences, while urban and environmental academics and professionals searched for new models to explain the interactions and for new solutions.

It is not surprising, then, to find quite a number of books related to different perceptions of pollution and of environmental issues. These range from considering labour unions and the environment, to women and the environment to the politics of the environment. The literature begins now to take a much more urban tinge through expansion of environmental concerns from green issues to brown and grey ones as well. Books related to solutions became more urban as well (See Galarza and Hurtado, 1991 and Gutierrez, 1991). While the traditional environmental concerns of natural resource conservation still dominated the agenda, new computer models of the interactions between population and environment, of the use and possible ways to conserve natural resources and of measures to abate atmospheric pollution recognised explicitly the urban settlement pattern of Latin America and the effect of it on the environment. A large step was taken in the literature from concern with the issue of natural resource conservation to that of the promotion of environmental sustainability. Sustainable development became a guiding principle of governmental policy (or at least lip service was paid to it!), and decentralisation as a way to alleviate social inequities and achieve sustainable growth became a serious policy alternative.

This turning point in the literary trend on the environment in Latin America from rural to urban was facilitated not only by the recognition of the interrelationships between economic development and environmental conditions, which were increasingly urban dominated, but also by the economic and political context of the region. Slowly, countries began to overcome their economic malaise and leave behind memories of dictatorial periods. Brazil and Argentina had elected governments once again, and democracy led to strong consideration of the need for decentralisation.

Along with this trend came the call from urban communities for recognition of their specific problems, and these difficulties had a very heavy environmental component. Pollution of air and water from factories and vehicles, as well as from garbage and excrement, caused public health in urban popular areas to be exceedingly poor. The lack of potable water, wastewater treatment and solid waste disposal, along with congestion, noise pollution and the hazardous wastes of small scale industries based in the communities, became important issues, and the people affected began to demand action.

Thus, during this period, a new trend showing the relationship between 
economic development and sustainability begins to emerge. The consequences of the large rural-urban migrations are now seen not only for their developmental and social significance, but new environmental problems resulting from the migrations are recognised as well. This, then, is the period during which urban problems converge with ecological or environmental problems and begin to be seen as urban ecological or urban environmental problems, such as air pollution due to transportation, water pollution due to mismanagement, floods due to urban generated deforestation, health problems due to urban environmental degradation, noise pollution due to the nature and density of urban activities and soil contamination due to the increasing demands of urban based manufacturing.

\section{- The 1993 to 1998 Period: Sustainable Development}

There seems to be a clear break in the literature in 1993, after the impacts of the United Nations Conference on the Environment held in Rio de Janeiro in 1992 began to be seen in the literature. The transitional period of the early 1990s was definitely over, and economic and political stability were accepted in the region as the norm. Sustainable development was now accepted as a global goal, with globalisation and interdependency pressuring countries in this region, as well as others, to adjust to international environmental standards.

What characterises the literature at present is its focus on environmental management issues. Incorporating the environment into public policy is no longer an issue; neither is the importance of the urban environment. The environment is now seen to have both rural and urban components and be brown and grey, as well as green. The burning issue now is how to manage the environment and who should do what. The various stakeholders involved now are not only national and regional governments, along with their decentralised lower organs, but also community groups outside the structure of government that may be formally organised (i.e., community based groups or CBOs) or not; organised invasions of empty urban land by rural based citizens relocating en mass to a city; the large number of non-governmental organisations (NGOs) so characteristic of social movements in many Latin American countries, but the private sector as well.

The private sector has a double role here, both as a polluter (most notably industry of all sizes), which needs to take measures to pollute less, and as a provider of urban infrastructure, again at various scales, which provides urban environmental services. These range from community level street sweeping, garbage collection and water provision, where their management is often tied to job provision and poverty alleviation, to city level waste treatment and disposal, where efficiency and low cost to the public treasury are stressed.

Finally, the last important trend to appear in this period is the necessity of providing an institutional and legislative framework to enable both community and municipal initiatives to be successful in dealing with the urban environment. Bolivia is perhaps the country in the region that has gone the farthest in this 
regard so far.

Despite the movement in the literature in the five periods from recognising the problems of the environment, to assessing the effects of pollution on the largely urban population, to recognising the systematic nature of the interconnections of the environment and the region's urban based economy and hence the need for sustainable development, to attempting to create the framework, policies and tools to manage the urban environment, it is clear that the problems of the past have not yet been solved. They remain subjects for further study and hence have not disappeared from the literature. That is why the current thematic mix includes the older subjects of rural development and the environment, environmental degradation in rivers, deforestation (first apparent in Period 1); the population and the environment, including the effects on people of all kinds of urban based pollution (Period 2); and the intimate connection of poverty to environmental degradation in cities, as well as the necessary steps to take to ensure sustainable development (Period 3). Nevertheless, the new themes of developing an institutional and regulatory framework, determining the proper the role of the private sector in urban environmental management and promoting environmental management in industry (Period 4) began to take precedence in the literature,

Sustainable development is the key phrase in the literature of this period. After the recognition of the relationship between economic development and the environment, as well as the identification of the problems stemming from this relationship, it became clear in the literature that a major issue of the turn of the $21^{\text {st }}$ century would be the sustainable development of cities. Thus, the Latin American literature of this period centres on the urban environmental problems that are consequences of human activities, as well as on their possible solutions, the various policy options to be considered in developing frameworks within which to implement the solutions, the necessary changes in management to support implementation, the new institutional arrangements required to sustain the solutions and the changes in human behaviour essential to making all of this happen. Ecological or environmental and urban issues finally converge in the literature.

\section{- The 1999 to 2017 Period: From Policy to Action}

However, the period spanning the last nineteen years became a transitional era of Urban Environmental Management, the conclusion of which was marked by Habitat III in Quito in 2016. During this timeframe, the literature moved from the consideration of concepts and policies to the recognition that meaningful programs and actions to enable sustainable development must be taken at the local level. Moreover, it has become evident that these actions must be undertaken in a systematic way within the framework of urban and regional planning. By 2002, many countries already had the laws, the institutions and even some judicial victories to support Urban Environmental Management, but serious issues of pollution remained due to systems of production and consumption 
that were not updated at the necessary pace (Rodriquez-Becerra and Espinoza, 2002). Thus, the time for policy development is over; it is time to act.

\section{Trends in the Periodic Literature}

After the search of the Spanish and Portuguese language Latin American literature on Urban Environmental Management appearing in books was completed and the trends perceived, the second stage of the Internet search proceeded to identifying journals or magazines from the region related to environmental issues. The purpose here was to confirm the findings of the initial search of books by seeing if the trends in journals were the same. This periodic search was done on a country-by-country basis for Argentina, Brazil, Chile, Colombia, Cuba Mexico and Peru

The first and most interesting observation from the periodic search of Latin American literature is that no single journal on the urban environment, or even on the much broader subject of the environment in general, existed in these seven countries prior to 1990! In fact, most of them did not appear until 1992/1993. Finally, given their nature and subject matter, it should be noted that journals related to the environment in Latin America appeared to reach an educated and sophisticated audience of academics, activists from leading NGOs, urban and/or environmental professionals and representatives of major industries and large enterprises, all of whom would be most interested in the most recent developments. These would extend to items of relevance regarding court cases, legislation, international environmental events and international standards. Consequently, it was assumed that the articles found in these journals in relation to the urban environment would parallel the regional environmental themes of Period 4 (i.e., sustainable development, economic policies, decentralisation, environmental law and legislation, etc.), as well as the call to action of Period 5, found in the Internet book search for Latin America. The assumption was confirmed in that all articles appearing in all journals from the seven countries were found to focus on the above-mentioned themes and mirror the trends described in the previous section. Finally, the trends found in the journals are also notable in that they are the same for all seven countries, which vary widely in level of development, type of economy, population, political system, social structure, physical endowment and location in the region.

\section{Conclusion}

As a result of the research undertaken, there is a clear trend of convergence of three elements in the Urban Environmental Management literature of Latin America that can be seen to have developed through the five periods analysed above. Initially (1970-1979), studies that were conducted regarding ecological or environmental problems were quite distinct from those analysing developmental issues and technological considerations. This trend remained the case in the second period (1980-1989), although a more comprehensive literature began to 
evolve on the development and growth of cities. Economics and population were the dominant regional issues at this stage. In the third period (1990-1992), however, the previously fast economic growth and the increased migration to the cities it set off, followed by the severe regional economic crisis and the rise of social movements, began to be reflected in the literature through discussion of the environmental consequences of these developments. A combination of human activity and environmental implications became the focus of many regional studies of this period. Next, the strands in the literature devoted to the environment, economic development and urbanisation in Latin America became intertwined at the beginning of the fourth period (1993-1997). Due to both external and internal pressures, it became widely recognised that the cities of Latin America could not cope any longer with their environmental problems without managing the processes generating them. Finally, the fifth and last period (19992017) became a period of transition. Progress has been made in the formulation and implementation of environmental policies, both at national, subnational and local levels, and in the development of various plans and instruments for environmental protection. Moreover, countries have environmental authorities today presenting different degrees of development, and most have a national executive agency specialised, either in the form of a ministry, committee on the environment or other equivalent entity (Ibid.). National and regional policies began to be transformed into local plans for action within the framework of urban and regional planning. This evolving focus of Urban Environmental Management was apparent in Habitat III as noted below.

Given the findings outlined in the previous sections and summarised above, it is important to note that this research is an ongoing project. This process awaits a further analysis the literature of the Spanish and Portuguese languages written in Latin America and about Latin America post 2017; that is after another meaningful period marked by a possible Habitat IV or other similarly significant event in urban planning and environmental management. Habitat III concluded with the drafting of a New Urban Agenda, highlighted by the Quito Declaration on Sustainable Cities and Human Settlements for All. This is a landmark document in Urban Environmental Management by pledging in Section 14. (c) to be guided, among others, by the principle:

Environmental sustainability, by promoting clean energy, sustainable use of land and resources in urban development as well as protecting ecosystems and biodiversity, including adopting healthy lifestyles in harmony with nature, promoting sustainable consumption and production patterns, building urban resilience, reducing disaster risks, and mitigating and adapting to climate change (Habitat III, 2016).

A further statement of note is that a fundamental driver of change is:

....reinvigorating long-term and integrated urban and territorial planning and design in order to optimize the spatial dimension of the urban form and to deliver the positive outcomes of urbanization. 


\section{Directions for Future Research}

All signs point, then, to the next phase of Urban Environmental Management being one of implementation at the local level. Future research, if undertaken, would determine if this is indeed the case. Issues likely to develop during such a Phase III analysis for Latin America include whether and how resources and authority for implementation will be transferred from central and regional governments to localities, whether they have the necessary technical and managerial expertise to run complex programs and if the international community will invest in these efforts.

The completion of a similar study of the overall English literature, as well as of companion studies of the literature representing a number of other languages and regions, of which this work would then form only a part, is another fruitful direction for further research. Thus, in another future study, the conclusions reached for the Latin American literature could be compared to those from the study of the overall English literature, as well as to those findings from the literature of other regions and/or languages to develop a time trend analysis, which would indicate the intensity of certain subjects (trends) according to time period and region. This would not only indicate the development of the field through identifying the most important issues and possible solutions at any point in time, but it would also give insight into which regions of the world are leaders in any particular aspect of Urban Environmental Management.

\section{References}

Baddeley, O., \& Fraser, E. (1989). Drawing the Line: Art and Cultural Identity in Contemporary Latin America. London: Verso.

Bartone, C. (1989). Environmental Issues in Urban Management. Draft INU Discussion Paper, Washington DC: The World Bank.

Berry, B. J. L., \& Horton, F. E. (1974). Urban Environmental Management: Planning for Pollution Control. Englewood Cliffs, NJ: Prentice-Hall.

Button, K. J., \& Pearce, D. W. (1989). Improving the Urban Environment: How to Adjust National and Local Government Policy for Sustainable Urban Growth. Progress in Planning, 32, 141-161.

Edelman, D. (1998). La ciudad como ecosistema: La administración del medio ambiente y la contaminación. In R. Eduardo, \& R. Daughters (Eds.), La Ciudad en en Siglo XXI (pp. 331-336). Washington DC: The Inter-American Development Bank.

Edelman, D. J., Procee, P., \& Acioly, C. (1997). Sustainable Urban Development and the Urban Poor in Rio de Janeiro. In the Conference: The Challenge of Environmental Management in Metropolitan Areas.

Fernández, R. (2000). Gestión ambiental de ciudades: Teoría crítica y aportes metológicos. México: Programa de las Naciones Unides para el Medio Ambiente.

Galarza, Y. and Carola, H. (1991). Saneamiento ambiental, disposicion de desechos y calidad de vida de las mujeres en Bolivia. Quito: Fundacion Natura.

Galilea, S. (1994). Modelo de gestión urbana para ciudades intermedias en América Latina. Santiago: CEPAL Comisión Económica para América Latina y el Caribe. 
Giradet, H. (1992). The GAIA Atlas of Cities: New Directions for Sustainable Urban Living. London: Gaia Books Limited.

Goodman, D., \& Redclift, M. (1991). Environment and Development in Latin America: The Politics of Sustainability. New York, NY: Manchester University Press.

Gutierrez, P. J. (1991). Hay polucion en Cuba? el dano creciente al medio ambiente se ha convertido en una amenza para el futuro del hombre. Cuba: Habana.

Habitat III (2016). New Urban Agenda. Draft Outcome Document (10 September 2016) for Adoption in Quito, Ecuador.

Hardoy, J. E., \& Satterthwaite, D. (1989). Environmental Problems in Third World Cities: A Global Issue Ignored? In Conference on Cities: The Mainspring of Economic Development in Developing Countries.

Leitmann, J. (1994). Rapid Urban Environmental Assessment: Lessons from Cities in the Developing World. Volumes 1 and 2, Urban Management Programme Discussion Papers 14 and 15. Washington DC: The World Bank.

https://doi.org/10.1596/0-8213-2790-9

Leitmann, J. (1999). Sustaining Cities: Environmental Planning and Management in Urban Design. New York, NY: McGraw-Hill.

Meier, R., Berman, S., Campbell, T., \& Fitzgerald, C. (1981). The Urban Ecosystem and Resource-Conserving Urbanism I Third World Cities (pp. 1-7, 32-44). Berkeley, CA: Institute for Urban and Regional Development.

Miranda, S., Liliana, J. C., \& Palacios, J. D. (1996). La situación de la gestión urbana ambiental en el Péru. In M. S. Liliana (Ed.), Ciudades para la Vida: Experiences exitoses y propuestas para la acción (PGU Serie Gestión Urbana No. 6). Lima: United Nations.

Mitlin, D., \& Satterthwaite, D. (1996). Sustainable Development and Cities. In C. Pugh (Ed.), Sustainability, the Environment and Urbanisation. London: Earthscan.

O'Brien, P. J. (1991). Debt and Sustainable Development in Latin America. In D. Goodman, \& M. Redclift (Eds.), Environment and Development in Latin America: The Politics of Sustainability. New York, NY: Manchester University Press.

Rees, W. (1996). Ecological Footprints of the Future. People \& the Planet, 5, 6-9.

Schuster, M., \& Edelman, D. J. (2002). Tendencias en la Gestión Urbana Ambiental en Latino América. Contraste Regional, 2, 183-204.

Schuster, M., \& Edelman, D. J. (2003). Latin American Trends in Urban Environmental Management. Clean Technologies and Environmental Policy, 5, 50- 60.

Vásconez, S. D. (2000). Hacia una nueva gestión ambiental urbana. In C. Fernando (Ed.), Desarrollo Cultural y Gestión en Centros Históricos (pp. 247-256). Quito: FLACSO.

White, R., \& Whitney, J. (1992). Cities and Environment: An Overview. In R. Stren et al. (Eds.), Sustainable Cities: Urbanization and the Environment in International Perspective (pp. 8-59). Boulder, CO: Westview Press. 


\section{Literature Reviewed}

Marquez Mayaudon, Enrique, El medio ambiente; Fondo de Cultura Economica, Mexico, 1973.

Tafur Hernandez, Isaac A., Polucion ambiental y su clasificación; Boletin de la Sociedad Geografica de Lima, Lima, 1975.

Marsico, Alfreado D. Estudio de las condiciones de higiene del aire de la ciudad de Buenos Aires, Universidad de Buenos Aires, Buenos Aires, 197? (exact year unknown).

Flores Ochoa, Jorge A., Distorciones en el suelo del ecosistema de la puna y los programas de cooperacion tecnica; Centro de Estudios Andinos, Peru, 1979.

Gligo, Nicolo, Implicancias medioambientales del modelo tecnologico predominante en la agricultura latino americana; Universidad Catolíca de Chile, Santiago, 1980.

Suarez, Ofelia, La basura es un tesoro: cultura del reciclaje, agricultura natural, no contaminante y otras vias hacia una sociedad ecologica; Direccion de Desarrollo Social de la Gobernacion del Distrito Federal, Caracas, 1981

Brailovsky, Antonio Elio, Politica ambiental de la Generacion del Ochenta; en Tres Estudios Argentinos, Ed. Sudamericana, Buenos Aires, 1982.

Roa Suarez, Hidroelectricas en Colombia: impactos ambientales y alternativas, Bogota, 1986.

Bouzas, Roberto et al, Conversion de deuda externa y financiacion del desarrollo en America Latina; Grupo Editor Latinoamericano, Buenos Aires, 1990.

Arturo Eichler et al., Deuda externa, desarrollo y ecologia; Ecuador: Grupo de Trabajo sobre Deuda Externa y Desarrollo, FONDAD, Quito, 1992.

Katz Ricardo B. y Gabriel del Favero V. (eds.), Medio ambiente y desarrollo: bases sociales, economicas, biologicas y juridicas para abordad los problemas de contaminacion ambiental en Chile; Centro de Estudios Publicos, Santiago, 1993.

Salazar Cambronero, Roxana, El derecho a un ambiente sano: ecologia y desarrollo sustentable, serie juridica, San Jose, 1993.

Antonio Azuela, Desarrollo sustentable: hacia una politica ambiental; Universidad Nacional Autonoma de Mexico, Mexico, 1993.

Rubio, Jose Luis Aceves (Ed), Desarrollo rural y medio ambiente: problematica ambiental en el estado de Veracruz, Colegio Profesional de Biologos del Estado de Veracruz, Xalapa, Veracruz, 1994.

Herzer, Hilda et al. Modelo teoretico-conceptual para la gestion urbana en ciudades medianas de América Latina. CEPAL Comisión Económica para América Latina y el Caribe: Santiago, 1994.

Bercovich, Nestor y Martina Chidiak, Reestructuracion industrial y gestion ambiental en el sector de celulosa y papel en Argentina; Centro de Investigaciones para la Transformacion Buenos Aires, 1994.

Tudela, Fernando, Poblacion y medio ambiente: los desafios de la complejidad, (place unknown), 1995.

Dalmau, Hector Horacio, El pais de los rios muertos: Argentina-Brasil: geopolitica de la destruccion ambiental; Buenos Aires, 1995.

Hajek, Ernst R., Pobreza y medio ambiente en America Latina: Una sintesis; Centro Interdisciplinario de Estudios sobre el Desarrollo Latinoamericano (year and place unknown).

Barboza, Luis C. The People of the Forest against International Capitalism: Systemic and 
Anti-systemic Forces in the Battle for the Preservation of the Brazilian Amazon Rainforest; Buenos Aires, 1996.

Fernández, María Augusta. Ciudades en riesgo: Degradación ambiental, riesgos urbanos y desastres. Red de Estudios Sociales en Prevención de Desastres en América Latina: Quito, 1996.

Lungo, Mario y Raquel Rolnik. Gestión estratégica de la tierra urbana. PRISMA: San Salvador, 1998.

Rodríguez-Becerra, Manuel y Guillermo Espinoza. Gestión ambiental en América Latina y el Caribe: Evolución, tendencias y principales prácticas. Banco Interamerícano de Desarrollo: Washington, DC, 2002.

Schuster, Micaela and David J. Edelman. "Tendencias en la gestión urbana ambiental en Latino América," Contraste Regional, Vol. 2, No. 3-4 (January-December 2002), pp. 183-204.

Brand, Peter y Fernando Prada. La invención de futuros urbanos: Estrategías de competitividad económica y sostenibilidad ambiental en los Cuatro Ciudades Principales de Colombia. Universidad Nacional de Colombia: Medellin, 2003.

Wilk, David, Carlos Pineda Mannheim y Dianna Moyer. Lineamientos estratégicos para la gestión ambiental urbana en Centroamérica. Banco Interamerícano de Desarrollo: Washington, DC, 2006.

Jost, Stefan, et al. Más allá de la seguridad democrática: Agenda hacia nuevos horizontes. Pontificia Universidad Javeriana: Bogotá, 2010.

Pilar, A. M., \& Diana, C. B. (2010). "La sostenibilidad ambiental urbana en colombia." Bitácora Urbano Territorial, 2(17), 73-93.

Ariza, N. S. F. “Manejo y separación de residuos sólidos urbanos. análisis comparativo entre madrid (españa) y el distrito especial industrial y portuario de barranquillas (colombia)"/"Management and separation of urban solid waste comparative analysis between madrid (spain) and the industrial and port special district of barranquilla (colombia)," Observatorio Medioambiental, 19, (2016), pp. 197-211.

In this section, a selection of journals consulted in the research, which provide further insight into the literature studied, is made. Again, this is not a complete list but merely suggestive of further directions to be pursued by the curious reader. They are listed by country.

Desastres y Sociedad. First published in 1993.

Revista del BID (Interamerican Development Bank). First published in 1994.

Medio Ambiente (no references). All articles published are from later than 1994.

Ambiente Ecologico. First published in 1996.

Habitat $y$ Urbanismo, published by the faculty of architecture in La Plata, Buenos Aires. First issued in 1996.

Estudios del Hábitat, Revista de la Universidad Nacional de La Plata. First published in 2002.

Revista Habitat Inclusivo HI. First published in 2003.

Revista Virtual Redesma. First published in 2011.

Armar la Ciudad, Revista del Instituto del Conurbano de la Universidad Nacional de General Sarmiento. First published in 2011.

Gestion y Ambiente. First published in 2014.

Jornal do Meio Ambiente. First published in 1996. 
Programa Salvadoreño de Investigación sobre Desarrollo y Medio Ambiente. Published 1998 - El Salvador (regarding Brazil).

Revista Brasileira de Gestão e Desenvolvimento Regional (G\&DR). First published in 2004.

City \& Time, Revista da Centro de Estudos Avançados da Conservação Integrada. First published in 2006.

Revista Geográfica Acadêmica. First published in 2007.

Revista de Geografia Norte Grande. 2010.

Ambiente Ahora. First published in 1990.

Ecomuna. First published in 1993.

Revista Ambiente y Desarrollo. First published in 1994.

Urbana: Revista de Urbanismo. First published in 1998.

Ambiente y Desarrollo. First published in 2001.

Revista eure. First published in 2006.

Bifucaciones: Revista de Estudios Culturales Urbanos. First published in 2013.

Bitácora Urbano Territorial, Revista de la Universidad Nacional de Colombia (Sede Bogotá). Facultad de Artes. Instituto de Investigaciones Hábitat.First published 1990.

Revista EAN. First published in 2008.

Bitácora 17. First published in 2010.

CUBAECO. First published in 1997.

EURE. 2013.

Calidad Ambiental. First published in 1993.

Boletin Ambiental. First published in 1996.

Ambiente sin Fronteras. First published in 1997.

Boletin de la Secretaria de Medio Ambiente.First published in 1997.

PNUMA. First published in 1998.

Mundo Urbano. Revista de la Universidad Nacional de Quilmes. First published in 2000.

Estudios Demográficos y Urbanos. First published in 2005

Academia XXII, Revista de la Facultad de Arquitectura de la Universidad Nacional Autónoma de México (UNAM). First published in 2009.

Interciencia. First published in 2010.

Revista Legislativa de Estudios Sociales y de Opinion Pública. First published in 2012.

Revista de Estudios Sociales. First published in 2013.

Ambiente y Desarrollo. First published in 2014.

Notimex. First published in 2015.

Revista Espacio y Desarrollo. First published in 1988.

ARKINKA: Revista de arquitectura, diseño y construcción. First published in 1995.

Atlas Ambiental Lima. First published in 2005.

Revista Peru Construye. First published in 2005.

ArchDaily Peru. First published in 2012.

Programa Salvadoreño de Investigación sobre Desarrollo y Medio Ambiente. First published in 1998-El Salvador. 
Letras Verdes: Revista Latinoamericana de Estudios Socioambientales, Departamento de Desarrollo, Ambiente y Territorio de FLACSO. First published in 1996-Ecuador

Environment \& Urbanization. Published in 2001-Netherlands (regarding Peru).

Cuadernos del Cendes. Published in 2003-Venezuela.

Cuaderno Venezolano de Sociologia. Published in 2007-Venezuela.

Observatorio Medioambiental. Published in 2016-Spain (regarding Colombia).

The numerous Internet sites, which follow, are those, which were searched in this study. They are organised by country, just as with the literature.

http://customw.com/ecoweb (Ecoweb Argentino)

http://www.invertir.com (Links al Web)

http://www.ambiente-ecologico.com (Revista Ambiente Ecologico)

http://www.microstar.com.ar (Revista Empresa y Medio Ambiente)

http://www.customw.com/gereamb/ (Revista Gerencia Ambiental)

http://www.grippo.com/argentina (Argentinean national directory of internet sites)

http://www.ungs.edu.ar/ms_ico/?cat=21 (Revista Armar la Ciudad)

http://revistas.unlp.edu.ar/Habitat/index (Revista de la Universidad Nacional de La Plata)

http://www.habitatinclusivo.com.ar/hi/04/ (Revista Habitat Inclusivo)

http://rbgdr.net/ (Revista Brasileira de Gestão e Desenvolvimento Regional (G\&DR) da Universidade de Taubaté)

https://www.iesa.ufg.br/n/3777-revista-geografica-academica

http://geograficaacademica.webng.com/ (Revista Geográfica Acadêmica, Laboratório de Geologia e Geografia Física do Instituto de Estudos

Sócio-Ambientais da Universidade Federal de Goiás (UFG).

http://ct.ceci-br.org/novo/revista(City\&Time, Revista da Centro de Estudos Avançados da Conservação Integrada (CECI))

http://www.melin.com.br (Journal on Environment)

http://www.gosnet.com.br (Urban Environment)

http://www.mma.gov.br (Agenda 21)

http://www.ambiental.com.br (Information network on the environment)

http://www.bifurcaciones.cl/ (Bifucaciones: Revista de Estudios Culturales Urbanos)

http://www.conama.cl (National Commission on Environment)

http://www.congreso.cl/biblioteca (Library of the National Congress)

http://www.rdc.cl/ambientales (Latin American network on environmental conflicts)

http://www.revistaurbano.cl/ (Urbana: Revista de Urbanismo, Universidad de Chile)

http://www.alternativa.com.co (Journal)

http://www.unv.org (University)

http://www.banrep.gov.co (Colombian Links)

http://dx.doi.org/10.5209/OBMD.54168 (Observatorio Medioambiental, España)

http://revistas.unal.edu.co/index.php/bitacora (Bitácora Urbano Territorial, Revista de la Universidad Nacional de Colombia)

https://search.proquest.com/docview/1677402482?accountid=2909

(Bitácora Urbano Territorial, Revista de la Universidad Nacional de Colombia) 
http://www.cubanet.org/entorno (CUBANET organisation)

$\underline{\text { http://redalyc.org/revista.oa?id=312 (Revista del Colegio de México, A.C.) }}$

http://revistas.unam.mx/index.php/aca (Academia XXII, Revista de la Facultad de Arquitectura de (UNAM)

http://www.mundourbano.unq.edu.ar/index.php/publicaciones-por-ano (Revista Mundo Urbano)

http://www.semarmap.gob.mx (Secretariat of Environment)

http://www.infosel.com.mx (Revista Tierra America)

http://uninet.mity.itesn.mx (Revista Calidad Ambiental)

http://mexico.web.com.mx (Ecological Web)

http://www.ine.gob.mx (National Institute of Ecology)

http://www.laneta.apc.org (Network on sustainable development)

http://www.cosmos.com.mx (Environmental management publications)

http://www.sistema.itesm.mx (Bulletin CEDSAL)

http://ekeko.rcp.net.pe (Scientific Peruvian Network)

http://www.urbanistasperu.org/inicio/inicio-a.htm (Sociedad de Urbanismo del Peru)

http://revistas.pucp.edu.pe/index.php/espacioydesarrollo/ (PUCP)

http://www.peruconstruye.net (Revista Peru Construye)

http://www.urbanoperu,com (Urbano Peru)

http://www.imp.gob.pe (Instituto Metropolitano de Planificacion)

http://www.archdaily.pe/pe/tag/planificacion-urbana (ArchDaily Peru)

http://www.arkinka.net (Revista ARKINKA)

http://www.urbanistasperu.org/inicio/inicio-a.htm (Urbanistas del Peru)

http://libraries.uc.edu/ (University of Cincinnati library website)

http://scholar.google.com/ (Google Scholar website)

http://www.loc.gov (Library of Congress)

http://www.scielo.org.ve/ (Scientific Electronic Library Online, Brazil page for Venezuela)

http://www2.planeta.com (Site on Latin America)

$\underline{\text { http://www.civila.com (Ecological links by country) }}$

http://www.envirobiz.com (International Environmental Information Network)

https://www.theguardian.com/cities/2017/jun/20/living-time-bomb-lima-flash-floods-per u-mudslides (The Guardian, UK)

Appearing here are other references used in the preparation of this paper, but which do not represent part of the literature search itself.

Miranda S., Liliana, et al. Perú, Hacia la construcción sostenible en escenarios de cambio climático. Editorial Universitaria: Lima, 2015.

Sánchez, L., \& Reyes, O. Medidas de adaptación y mitigación frente al cambio climático en América Latina y el Caribe: Una revisión general.2015.

Sustainable Cities Programme. SCP/LA21 en Peru. UN-Habitat, Nairobi 2009. 


\section{Annex: Key Word List}

The Key Word List represents the most common themes appearing in the Latin American literature on Urban Environmental Management between 1970 and 1998. The incidence of their occurrence in the Internet literary search represents the key element used in tracing the trends in the literature, and based upon this, the four distinct periods discussed in Section 4 emerged. The words are described below to provide the reader with the meaning behind the use of a word or phrase in the literature, but these descriptions are not necessarily definitions of the words themselves. The reason for developing these descriptions is that during the course of this research, it became obvious that many key words used in the Internet searches of books and the periodic literature make reference to issues that are not necessarily made explicit merely by providing a conventional definition of the term, but which are clearly related to this study. The key words described below, then, are the most significant and frequently occurring ones found in the search and are presented here merely for purposes of clarification. Figure 2, which follows the Key Word List, presents the pattern of occurrence of each word by period.

- Environmental Impacts: is a key word referring to the effects on the overall environment and on various ecosystems as a consequence of human activities such as agriculture, urban transportation, atmospheric pollution, poverty, etc.

- Demography: in the literature reviewed refers to population growth and the expansion of the urban space due to migration.

- Water: refers to both water supply and water quality (including water pollution), but not to water treatment.

- Air: generally refers to atmospheric pollution as a consequence of $\mathrm{CO}_{2}$ emissions from transportation.

- Soil/Land: usually refers to the extensive use of land for agricultural activities, and its implications on soil quality.

- Transport: refers in the literature both to urban transportation systems and the air pollution they produce.

- Energy: is a key word that normally refers to energy generated pollution as a consequence of large infrastructure projects such as dams, power plants, road networks, etc.

- Urban Development: in the Latin American literature usually refers to issues related to architecture and urban growth, and to the necessity to satisfy the increasing demand for urban housing.

- Ecology: is a key word in the literature reviewed that normally refers to ecosystem disruptions, such as have occurred in the case of the Amazon and some other forest areas in the region.

- Waste: initially appears in the literature not as waste per se, but mainly as the value of waste and its importance with regard to the urban environment. 


\begin{tabular}{|c|c|c|c|c|c|}
\hline & $1970 / 1979$ & $1980 / 1989$ & $1990 / 1992$ & $1993 / 1998$ & 1999-2017 \\
\hline Envi. Impacts & $0 \%$ & $60 \%$ & $10 \%$ & $10 \%$ & $0 \%$ \\
\hline Demography & $10 \%$ & $0 \%$ & $0 \%$ & $0 \%$ & $5 \%$ \\
\hline Water & $20 \%$ & $20 \%$ & $0 \%$ & $0 \%$ & $0 \%$ \\
\hline Air & $10 \%$ & $0 \%$ & $0 \%$ & $0 \%$ & $16 \%$ \\
\hline Soil/Land & $10 \%$ & $0 \%$ & $0 \%$ & $0 \%$ & $11 \%$ \\
\hline Transport & $10 \%$ & $10 \%$ & $0 \%$ & $0 \%$ & $0 \%$ \\
\hline Energy & $10 \%$ & $10 \%$ & $0 \%$ & $0 \%$ & $5 \%$ \\
\hline Urban Development & $10 \%$ & $30 \%$ & $0 \%$ & $0 \%$ & $5 \%$ \\
\hline Ecology & $20 \%$ & $20 \%$ & $0 \%$ & $0 \%$ & $5 \%$ \\
\hline Waste & $0 \%$ & $10 \%$ & $10 \%$ & $0 \%$ & $5 \%$ \\
\hline Envi. Pollution & $10 \%$ & $10 \%$ & $0 \%$ & $0 \%$ & $5 \%$ \\
\hline Urban Pollution & $0 \%$ & $0 \%$ & $0 \%$ & $0 \%$ & $5 \%$ \\
\hline Population \& Envi. & $0 \%$ & $0 \%$ & $20 \%$ & $10 \%$ & $0 \%$ \\
\hline Health & $0 \%$ & $10 \%$ & $20 \%$ & $0 \%$ & $0 \%$ \\
\hline Women & $0 \%$ & $0 \%$ & $0 \%$ & $0 \%$ & $0 \%$ \\
\hline Perceptions & $0 \%$ & $20 \%$ & $0 \%$ & $0 \%$ & $0 \%$ \\
\hline Environmental Law & $0 \%$ & $0 \%$ & $0 \%$ & $20 \%$ & $5 \%$ \\
\hline Environmental Policy & $0 \%$ & $0 \%$ & $70 \%$ & $60 \%$ & $5 \%$ \\
\hline Sustainability \& Economics & $0 \%$ & $0 \%$ & $40 \%$ & $10 \%$ & $5 \%$ \\
\hline Sustainability/Decentralization & $0 \%$ & $0 \%$ & $10 \%$ & $0 \%$ & $5 \%$ \\
\hline Envi. Management & $0 \%$ & $0 \%$ & $10 \%$ & $30 \%$ & $5 \%$ \\
\hline City Plng \& Mgmt. & $0 \%$ & $10 \%$ & $0 \%$ & $0 \%$ & $21 \%$ \\
\hline Poverty & $0 \%$ & $0 \%$ & $10 \%$ & $10 \%$ & $5 \%$ \\
\hline Indian Communities & $0 \%$ & $10 \%$ & $0 \%$ & $10 \%$ & $0 \%$ \\
\hline Social Movements & $0 \%$ & $10 \%$ & $10 \%$ & $0 \%$ & $5 \%$ \\
\hline Sustainable Devel. & $0 \%$ & $0 \%$ & $0 \%$ & $40 \%$ & $47 \%$ \\
\hline Risk \& Urban Disaster & $0 \%$ & $0 \%$ & $0 \%$ & $0 \%$ & $16 \%$ \\
\hline Prevention/ Mitigation & $0 \%$ & $0 \%$ & $0 \%$ & $0 \%$ & $5 \%$ \\
\hline Envi. Transforma. \& Degrada. & $0 \%$ & $0 \%$ & $0 \%$ & $0 \%$ & $5 \%$ \\
\hline Innovative Instru. of Urb. Mgmt & $0 \%$ & $0 \%$ & $0 \%$ & $0 \%$ & $53 \%$ \\
\hline Participation & $0 \%$ & $0 \%$ & $0 \%$ & $0 \%$ & $47 \%$ \\
\hline Urban Eco. Footprint & $0 \%$ & $0 \%$ & $0 \%$ & $0 \%$ & $11 \%$ \\
\hline Envi. Quality \& Envi. Indicators & $0 \%$ & $0 \%$ & $0 \%$ & $0 \%$ & $37 \%$ \\
\hline Complete Systems & $0 \%$ & $0 \%$ & $0 \%$ & $0 \%$ & $26 \%$ \\
\hline Public-Private/New Eco. Instruments & $0 \%$ & $0 \%$ & $0 \%$ & $0 \%$ & $26 \%$ \\
\hline Intermediate Cities & $0 \%$ & $0 \%$ & $0 \%$ & $0 \%$ & $11 \%$ \\
\hline Environmental Crisis & $0 \%$ & $0 \%$ & $0 \%$ & $0 \%$ & $5 \%$ \\
\hline
\end{tabular}

Figure 2. Frequency of Occurrence of Key Words by Period. ${ }^{*}$ The figures used here represent the percentages of all relevant references occurring in the five periods in which each key word appears, with the darker the shading, the greater the frequency of occurrence. 
- Environmental Pollution: refers to pollution of all the environmental compartments (i.e., air, water and soil).

- Urban Pollution:

- Population and Environment: is a term that recognises the interrelationships between population and its surroundings.

- Health: as a key word refers here to human health as a consequence of environmental pollution.

- Woman: as a theme appears in the third period (i.e., 1990-1992) of the Latin American Urban Environmental Management literature and looks at the impact of environmental pollution on the daily lives of women.

- Perceptions: as used in the literature reviewed, refers to new perceptions of life that have been developed related to environmental problems in general, but focused on the urban environment (i.e., a new understanding of the importance of human surroundings and the cities in which humans live).

- Environmental Law: refers both to national and international law, which has the aim of solving and controlling trends which are harmful to human life and the urban environment.

- Environmental Policy: within the context of this paper is related to the environmental problems associated with economic growth and to the policy proposals for achieving sustainable development.

- Sustainability and Economy: in the Latin American literature generally refers to debt equity swaps; i.e., the exchange of sustainable practices and protection of the environment for national debt relief.

- Sustainability and Decentralisation: in the Latin American literature is a theme characteristic of the third period of this research (1990-1992), which generally refers to the geographic decentralisation of economic activity considered as a solution to alleviate social inequities. At present, however, the term would be more related to political decentralisation.

- Environmental Management: is used in the literature to mean environmental management in the technical sense and also to describe the governmental and institutional approaches and methods to cope with urban environmental problems, the severity of which is increasingly being recognised.

- City Planning and Management: appears in the second period (i.e., 19801989) of this study of the Latin American literature on Urban Environmental Management in relation to the physical, ecological and landscape aspects of urban areas.

- Poverty: is described in the urban literature reviewed here only as part of the interrelated chain comprising conservation, environmental problems, and socio-economic development.

- Indian Communities: is a term that relates to environmental problems and the sustainable practices of Indian communities. This is often related to the issue of the Amazon and the impacts of modern civilisation on Indian life.

- Social Movements: is a key word that refers here to the social movements 
that were initiated due to the recognition of the importance of environmental issues. The focus is usually on the impacts of human activities on sectors of Latin American society which experience discrimination (e.g., Indian communities and the urban poor).

- Sustainable Development: in the Latin American literature is, on the one hand, clearly defined with regard to economic growth within environmental constraints, but, on the other hand, it is used to contrast the current pattern of development with the needs of the region by analysing the multiple connections between economy and ecology and then philosophising about the utopian future of Latin America

- Risk and Urban Disaster: In Latin America, the management of risk and urban disaster has been a reactionary movement that has pushed different levels of government to assess and address risk. The aftermath of environmental disasters, the vulnerability of new settlements, the sizes of cities, and international pressures have pushed municipalities and national governments to take charge of these issues.

- Prevention and Mitigation: are activities that have an objective of stabilizing the concentration of greenhouse gases in the atmosphere. Major efforts in Latin America have revolved around addressing deforestation issues, mechanisms of sustainable development "desarrollo limpio," energy efficiency, management of urban waste, green credits, carbon taxes, renewable energy policy, user-oriented energy and fuel alternative campaigns, public transporttation improvements, land planning, technological improvements in agriculture, residential water programs, and programs targeting high polluting industry.

- Environmental Transformation and Degradation: Discussion of Urban Environmental Management commonly refers to degradation as the environmental damage caused by the fast conversion of natural land into urbanized area for the formation of settlements.

- Innovative Instruments of Urban Management: The Latin American literature on urban environmental management has evolved from the discussion of policy and its framework to more studies including technology as a tool to aid in achieving sustainability/environmental goals. This covers studies using GIS (Geographic Information Systems), technocratic planning, data-guided decision making, innovation through new financing tools, sophisticated indexes, the usage of certificates or reforestation incentives "certificados de incentivo forestal," the assessment of ecological costs, and qualitative indicators of progress such as examining the quality of life.

- Participation: in the literature reflects a greater emphasis on the inclusion of public participation and public consultation in decision making at local/ regional levels, as well as at the national level. Participation also includes public decisions, consistent leadership, inclusion of vulnerable population voices, as well as local authorities and public consultation. 
- Urban Ecological Footprint: refers to the natural capital necessary to sustain urban growth in Latin American cities.

- Environmental Quality and Environmental Indicators: are parameters and measures that provide quantitatively insight into common qualitative topics such as the state of the environment with regard to aspects of its ecological nature, human-centered sustainability, etc.

- Complete Systems and Integration of Instruments in Plans: reflects a progressive shift to the use of local and national level plans to help integrate in a holistic, integrated, systemic way different aspects of environmental management to enable a complex, interdependent discourse the management of environmental topics in Latin American cities.

- Public/Private Partnerships, New Economic Instruments and Economic Efficiency: refer to creative solutions to financial instability at the local level as a result of the significant presence of the private sector in the economic growth of Latin American cities, which enables the formulation of policy for Urban Environmental Management.

- Intermediate Cities: is a term commonly used to address medium sized cities, which are sometimes the product of rapid growth caused by rural-urban migration.

- Environmental Crisis: is triggered by outdated infrastructure, events such as El Nino or La Nina, the vulnerability of self-made construction, and settlement on inappropriate land; these are costly and fatal events that have moved municipalities and national governments to think more seriously about the environmental management of Latin American cities.

Submit or recommend next manuscript to SCIRP and we will provide best service for you:

Accepting pre-submission inquiries through Email, Facebook, LinkedIn, Twitter, etc. A wide selection of journals (inclusive of 9 subjects, more than 200 journals)

Providing 24-hour high-quality service

User-friendly online submission system

Fair and swift peer-review system

Efficient typesetting and proofreading procedure

Display of the result of downloads and visits, as well as the number of cited articles

Maximum dissemination of your research work

Submit your manuscript at: http://papersubmission.scirp.org/

Or contact cus@scirp.org
} 